\title{
The influence of climatic factors on the performance of photovoltaic panels
}

\author{
Mirela-Ionela Mihai ${ }^{1 *}$, Vladimir Tanasiev ${ }^{1}$, Adrian Badea ${ }^{1,2}$ and \\ Ruxandra Vidu ${ }^{3}$ \\ ${ }^{1}$ University POLITEHNICA of Bucharest, Faculty of Power Engineering, \\ Bucharest, 060042, Romania \\ ${ }^{2}$ Academy of Romanian Scientists, 050094, Romania. \\ ${ }^{3}$ University of California, Davis, Department of Chemical Engineering and \\ Materials Science, Davis CA 95616, United States of America. \\ Corresponding Author: *mihaimirelaionela@gmail.com
}

\begin{abstract}
Solar energy is a clean energy, environmental friendly, abundant and also free. There are various commercially available forms to capture solar energy such as photovoltaic panels (PV), solar thermal electricity and solar panels. Due to high energy consumption in the buildings and to the laws imposed by European Union to reduce the energy consumption, PVs are ideal solutions for residential houses and commercial buildings in regions with a high solar irradiation levels. This paper presents a case study of the influence of environmental factors (i.e. ambient temperature, snow and dust) the PV performance. The evaluation consists in temperature measurements, infrared (IR) imagines taken with a thermovision camera and visual inspections of PV. Measurements performed on the PV system were recorded during one year period.
\end{abstract}

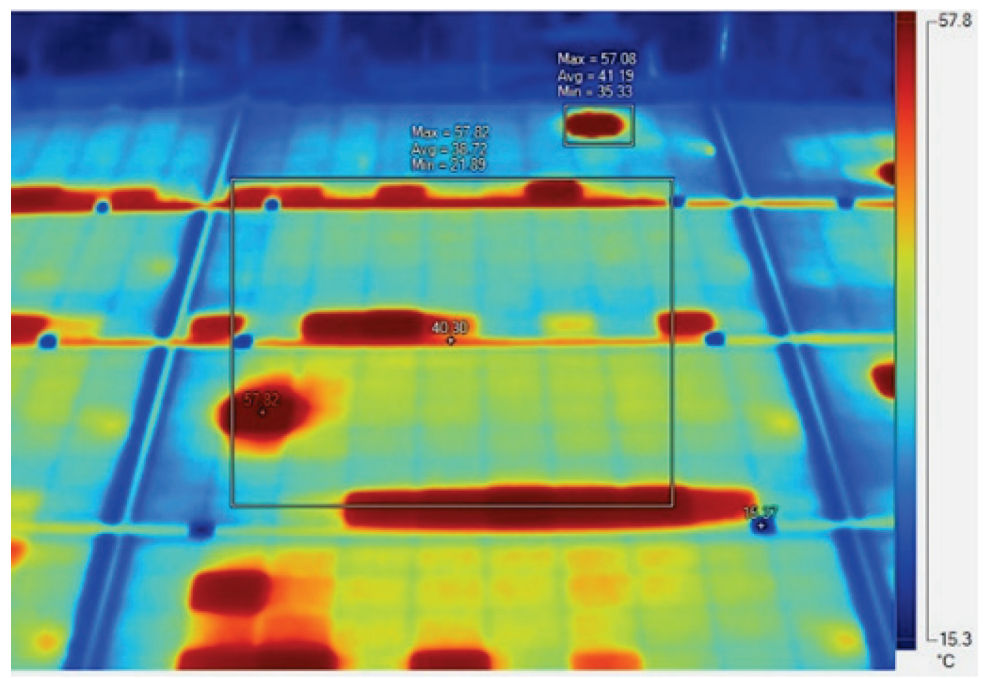

IR mapping of the heat dissipation in a PV module. 


\section{Introduction}

In our century, the energy has become more valued since the energy from conventional source is about to deplete sooner than we expected. At the same time energy consumption increases dramatically worldwide, especially in tertiary and residential sector $[1,2]$. For this reason the number of photovoltaic panels installed in the world has increased. Buildings are the key part in the expansion of PV system. They can be applied on the facade surface, roof or installed next to the building in the parking lot $[3,4]$.

By the end of 2013 worldwide installed PV had a total production of $140 \mathrm{GW}$. European Union is holding a leading position with $57 \%$ (i.e. 80.7 GW), followed by Asia and USA [5]. The first five countries in Europe that produce solar photovoltaic energy are United Kingdom (3.4 GW), Germany (3.3 GW), Italy (1.6 $\mathrm{GW})$, Romania (1.1 GW) and Greece (1 GW) [5].

The total global output power of PV in 2014 was $\sim 160 \mathrm{TW} / \mathrm{h}$ (terawatt per hour) estimated by International Energy Agency (IEA), which means $0.85 \%$ of the total energy demand in the world [6]. The IEA predicted that by the year 2020, the global PV production would increase to 379 TWh/year [7, 8].

Therefore, it is important for PV systems to operate at the maximum design capacity to provide a constant and reliable power delivery over their estimated lifetime.

Environmental parameters such as ambient temperature, wind, dust and snow can influence the PV system performance. This paper discusses how the environment factors reduce the PV performance.

\section{Presentation of PV system}

Study of PV systems was performed on 13 PVs that were installed on the roof of a residential building located in the University "Politehnica" of Bucharest
(UPB). The PVs have a south orientation and a $15^{\circ}$ tilt angle. These PV are made of polycrystalline solar cells with an efficiency of $13.4 \%$ have a nominal power of $230.7 \mathrm{~W} / \mathrm{PV}$, a surface area of $1.67 \mathrm{~m}^{2}$ /PV, with a total aria of $21.75 \mathrm{~m}^{2}$ for the 13 panels. PV modules are connected to an inverter that transforms direct current (DC) into alternative current (AC). The surplus energy produced by the PV system is introduced in a local electricity grid of Politehnica University.

The specification for the polycrystalline PV used for this study are listed in Table 1 below.

Table 1. PV specifications

\begin{tabular}{|c|c|}
\hline Parameter & Value \\
\hline Short-circuit current [A] & $\mathrm{I}_{\mathrm{SC}}=8.24$ \\
\hline Open-circuit voltage [V] & $\mathrm{V}_{\mathrm{OC}}=36.7$ \\
\hline Current at nominal power [A] & $\mathrm{I}_{\mathrm{mp}}=7.55$ \\
\hline Voltage at nominal power [V] & $\mathrm{V}_{\mathrm{mp}}=29.8$ \\
\hline Maximum power [W] & $P_{\text {max }}=225$ \\
\hline$P_{\max }=V_{m p} \cdot I_{m p}$ & \\
\hline $\begin{array}{l}\text { Tension/ temperature } \\
\text { coefficient }[\mathrm{V} / \mathrm{K}]\end{array}$ & $\mathrm{K}_{\mathrm{v}}=-0.33$ \\
\hline Current/ temperature & $\mathrm{K}_{\mathrm{i}}=0.04 ;$ \\
\hline $\begin{array}{l}\text { Number of cells in series } \\
\text { Numbient }[A / K]\end{array}$ & $\mathrm{N}_{\mathrm{S}}=60$ \\
\hline $\begin{array}{l}\text { Temperature at Standard Test } \\
\text { Conditions }\left[{ }^{\circ}\right]\end{array}$ & $\mathrm{T}_{\mathrm{STC}}=25^{\circ} \mathrm{C}$ \\
\hline $\begin{array}{l}\text { Irradiance at } \mathrm{STC}[\mathrm{W} / \mathrm{m} 2] \text { at } \\
\mathrm{AM}=1.5 \text { spectrum }\end{array}$ & $\begin{array}{l}\mathrm{G}_{\mathrm{STC}}= \\
100 \mathrm{~W} / \mathrm{m}^{2}\end{array}$ \\
\hline
\end{tabular}

The technical data sheet of the PVs list the operating temperature of the PV module, which is between $-40{ }^{\circ} \mathrm{C}$ and + $85^{\circ} \mathrm{C}$. On the roof of the house is installed one sensor of temperature and one pyrometer that measures the solar radiation that falls on the surface of the PV module. Climate conditions play an important role in the energy production of photovoltaic panels. In Bucharest summers are very hot with temperatures up to $40{ }^{\circ} \mathrm{C}$ and in winter temperature drops down to $-15^{\circ} \mathrm{C}$.

\section{Result and discussion 3.1 Analysis of $P V$ performance}


The energy delivered by the PV system using data collected from the 13 PV modules installed on the roof of the UPB residential house over one year was recorded.

Figure 1 presents the maximum energy produced by the PV system. During the month of July, $225.10 \mathrm{kWh} /$ month has been produced, while the month of November showed the minimum energy produced by $\mathrm{PV}$, i.e. $19.50 \mathrm{kWh} /$ month. The total energy delivered by the PV system over one year is $1433.45 \mathrm{kWh} /$ year.

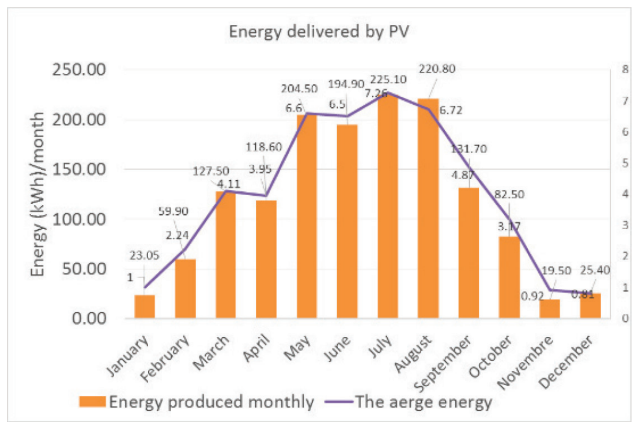

Figure 1. Energy produce by the PV system.

Figure 1 shows that the energy produced by $\mathrm{PV}$ in winter months from November to February 2014 decreases drastically due to the low solar radiation. Figure 2 shows an example of a typical solar radiation in January, which correlates well with the power output for that period of time. The power generated by the PV system depends on the solar radiation. When the solar radiation is below 100 $\mathrm{W} / \mathrm{m}^{2}$, the power of PV tends to zero. In spring and summer months, we have an increases in energy delivered by PV.

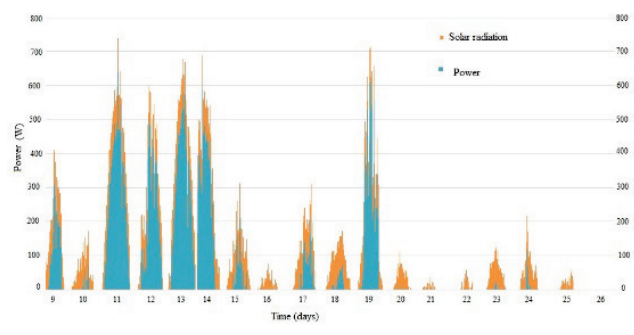

Figure 2. Solar radiation and power output of PV in period of 9-26 January 2014

\subsection{Analysis of PV module with infrared (IR) thermovision camera}

The IR analysis is based on the property of materials to emit electromagnetic radiation and depend on the temperature of materials [9]. In other words, when the objects have a higher temperature than temperature $\mathrm{T}=0 \mathrm{~K}$, they emit energy in the form of radiation [10]. Depending on wavelength, the radiation can be of several types: $\gamma$ radiation, X-rays, ultraviolet, visible, infrared and radio (microwave). Thermal radiation is the result of transforming the internal energy of bodies in energy with wavelengths between $0.1 \div$ $100 \mu \mathrm{m}$, including a portion of the ultraviolet and visible radiation entirely and infrared spectra [10].

This property of objects to emit the radiation is explained by several laws such as: Stefan-Boltzmann, Planck's and Wien. For example the Stefan-Boltzmann relation express the total power output emitted by a black body which is proportional with temperature [10].

$$
\begin{aligned}
& E_{0}=\sigma_{0} S T^{4}=C_{0}\left(\frac{T}{100}\right)^{4}\left[\mathrm{~W} / \mathrm{m}^{2}\right] \\
& \text { Where: }
\end{aligned}
$$

$$
\sigma_{0}=5.67 \cdot 10^{-8} \quad ; \quad C_{0}=5.67
$$

$\left[\mathrm{W} /\left(\mathrm{m}^{2} \mathrm{~K}^{4}\right)\right]$ - black body coefficients [10].

For a gray body which not absorb all the incident radiation and not emits as much of energy like black body, is characterized by emissivity, $\varepsilon<1$.

$E=\varepsilon(T) E_{0}=\varepsilon(T) C_{0}\left(\frac{T}{100}\right)^{4}\left[\mathrm{~W} / \mathrm{m}^{2}\right]$

$\varepsilon(\mathrm{T})$ - represent the total emission factor of body [10].

The infrared images on PV system help diagnosticate defect in a PV module and identify the solar cells that are working at a higher temperature than normal.

Figure 3 presents an IR image of a panel, which was obtained with a thermovision camera. In this image, the hot areas are red-brown and the cold areas are blue (Figure 4). The solar cells with a higher temperature are called "hot spot" in 
the literature. The hot spot represents an area of a PV panel that has a high temperature. This temperature could damage the cells efficiency, since the efficiency of cell decreases with the increase temperature. For instance if the temperature rise with $1{ }^{\circ} \mathrm{C}$ then losses of energy is $0.5 \%$ in a crystalline PV model [4].

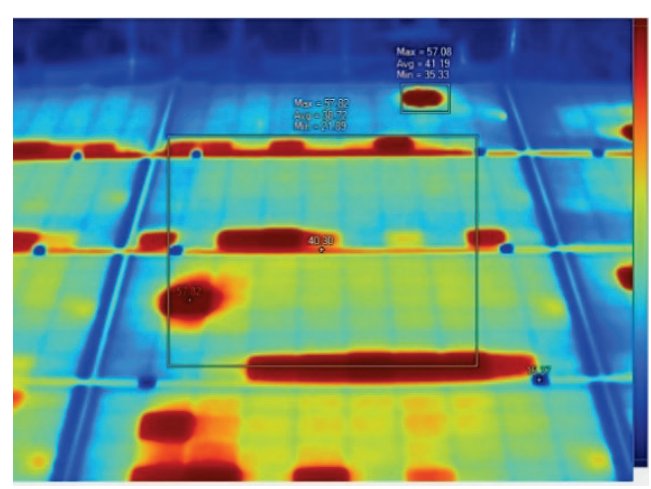

Figure 3. IR image with thermovision camera of a portion of the PV panel.

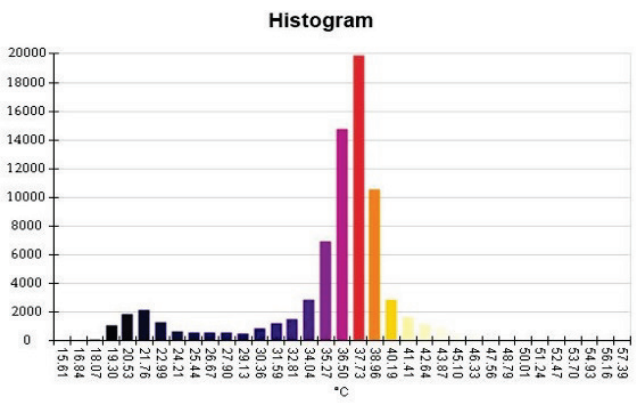

Figure 4. Graphical representation on IR temperature histogram on pixel.

The specification of IR image used for this study are listed in Table 2.

appearance in a PV module [9] could be the deposition of dust, partial shadow and bad connection between cells. Also, causes for hot spots are, shortcuts or certain cases when the PV modules were not placed at a minim distance of $25 \mathrm{~mm}$ from the roof surface and thus they overheat due to poor ventilation $[11,12]$.
Shadow or dusts on a solar cell causes a loss in efficiency due to the fact that the energy is consumed as heat instead of being produced as electricity $[9,13]$.

Table 2. Image Info IR

\begin{tabular}{l|l}
$\begin{array}{l}\text { Background } \\
\text { temperature }\end{array}$ & $22.00^{\circ} \mathrm{C}$ \\
\hline $\begin{array}{l}\text { Emissivity } \\
\text { Average }\end{array}$ & 0.95 \\
$\begin{array}{l}\text { Temperature } \\
\text { Image Range }\end{array}$ & $35.74^{\circ} \mathrm{C}$ \\
Camera Model & $15.37^{\circ} \mathrm{C}$ to $57.82^{\circ} \mathrm{C}$ \\
IR Sensor Size & $200 \times 150$ (pixels)
\end{tabular}

The principal cause of the hot spot On the other side, solar cell that operates at a higher temperature then the rest of the cells is considerate an error in the fabrication of PV module. For this reason the solar cell with high temperature can damage the efficiency of PV system even if the system is operating for a short period of time.

Figure 5 presents an image of the PV panel (in visible light). On this panel there is bird dirt that induces solar cell overheat. Correlating the visual observation with the IR image in Figure 3, it can be easily notice that the location where the bird dirt was observed has a maximum temperature of about $57.08^{\circ} \mathrm{C}$, average $41.19^{\circ} \mathrm{C}$ and the minimum $35.33^{\circ} \mathrm{C}$.

M.A. Munoz et al. [9] analyzed the early degradation of Si PV modules and explained the causes of certain failures in the PV module. The methods used for determination of failure detection was:

a) Visual inspection;

b) Indoor and outdoor power measurement;

c) Infrared images (IR);

d) Lock at thermography (LIT);

e) Electroluminescence (EL) and photoluminescence (PL) imaging techniques; 
f) Resonance ultrasonic vibrations (RUV) technique.

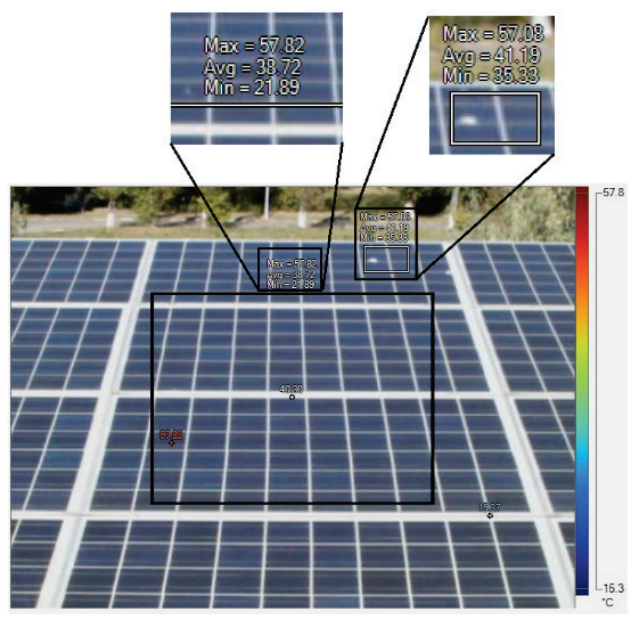

Figure 5. PV examined in visible field

All these methods give information on the causes generating defects such yellowing and browning; delamination, bubbles, cracks in the solar cells; defects in the anti-reflective coating (ARC), hot spots, etc. [9].

Claudio Ferrara and Daniel Philipp [14] haves studied the climatic stress that affect the PV module such as solar irradiation, UV irradiation, humidity, wind, snow, rain, hail, high/low temperatures, temperature changes, salt, sand and dust. The result of this study [14] shows that the climate tests represent the most rigorous test in the current standards.

Abhishek Rao et al. [15] performed a study on the influence of the dust deposited on the PV surface on the performance of PV. In their experiment, tow PV modules setup on the roof, where one PV was clean and the other one was covered with dust. The performance of the
PV modules was analyzed by recording the $\mathrm{I}-\mathrm{V}$ curves under different solar radiation [15]. The result of this experiment was that the dust deposition on the PV surface does not affect the open circuit voltage of the panels. Instead the power loss of the dusted panel which was 5 to $6 \%$ of the maximum power output. Losses recorded on the dusted panel depended on the density of dust deposited on the panel [15]. For example, if the dust surface density is $1.4 \mathrm{~g} / \mathrm{m}^{2}$ then loses of PV power is $5-6 \%$, while the power loss is between $45-55 \%$ if the dust density is $7.1 \mathrm{~g} / \mathrm{m}^{2}$.

\section{Conclusion}

This research work was focused on the study of photovoltaic panels that generated energy over one year for a residential house in Bucharest, Romania. The result of the measurements performed in real time showed that the power output is closely related to the solar radiation and varies depending on the season.

From the IR imaging we realized that the PV module analyzed in this work has solar cells exhibiting a higher temperature compared to the others. The results show that the high temperature solar cells lose energy by heat and actually consume energy instead of producing. The main cause found in this case is due to the dirt dust deposited on the surface of PV. To have a longer lifetime, the PV must be maintain clean in summer, and to be washed and cleaned of snow in winter.

\section{Acknowledgment}

The work has been funded by the Sectorial Operational Programmer Human Resources Development 2007-2013 of the 
Ministry of European Funds through the Financial Agreement POSDRU/ 159/1.5/S/132395.

\section{References}

[1] L.Rongen. Passive house design: a benchmark for thermal mass fabric integration. Woodhead Publishing Limited 2012.

[2] Commission E. Directiva 2009/28/EC a Parlamentului European si a Consiliului din 23 Aprilie 2009 privind promovarea utilizării energiei din surse regenerabile, Jurnalul Oficial al Uniunii Europene. 2009.

[3] Laurentiu Fara MRM, Vladimir Iancu, Silvian Fara, Dragos Comaneci Corneliu Cincu, Catalin Zaharia, Dumitru Finta, Mihai Iancu. Fizica si tehnologia celulelor solare si sistemelor fotovoltaice. Bucuresti: Editura Academiei Oamenilor de Stiinta din Romania; 2009.

[4] Narciso Moreno LGD. Instalatiile fotovoltaice. 2010.

[5] Commission E. JRC SCIENCE AND POLICY REPORTS. 2014.

[6] (IEA) IEA. PVPS Report Snapshot of Global PV 1992-2013.

[7] Outlook WE. Global Energy Trends. 2013.

[8] EREC. Renewable Energy Scenario to 2040,

http://www.erec.org/fileadmin/erec_docs/
Documents/Publications/EREC_Scenario 2040.pdf.

[9] M.A. Munoz MCA-G, Nieves Vela, F. Chenlo. Early degradation of silicon PV modules and guaranty conditions. ELSEVIER. 2011; Solar Energy 85:226474.

[10] Badea A. Bazele Transferului de caldura si masa. Bucuresti: Editura Academiei Romane; 2005.

[11] T. Tsoutsos ST, Z.Gkouskos. "Sisteme PV - Formarea si certificarea instalatorilor in Europa", Construire, Arhitectura si Tehnologie 2010.

[12] R. Alonso ERT, T. Tsoutsos, Z. Gkouskos (ENV/TUC), O. Zabala, J.R. López "Potentialul si Beneficiiele BPIV", Intelligent Energy Europe. 2009.

[13] Ana-Maria CROITORU AB. Water Cooling of Photovoltaic Panels From Passive House Located Inside The University Politehnica Of Bucharest. UPB Sci Bull, Series C. 2013;75.

[14] Claudio Ferrara DP. Why Do PV Modules Fail? ELSEVIER. 2012;Energy Procedia 379-87.

[15] Abhishek Rao RP, Monto Mani, Praveen Ramamurthy. Influence of dust deposition on photovoltaic panel performance. ELSEVIER. 2014;Energy Procedia 54 690-700. 